\title{
COMPETITIVENESS OF INDONESIAN TEA IN INTERNATIONAL MARKET
}

\author{
Jauhar Samudera Nayantakaningtyas ${ }^{*}$, , Arief Daryanto*), and Imam Teguh Saptono ${ }^{* *}$ \\ *) Sekolah Bisnis, Institut Pertanian Bogor \\ Jl. Raya Pajajaran, Bogor 16151 \\ **) PT. Bank BNI Syariah \\ Jl. HR Rasuna Said Kav 10-11, Lt 3-6, Jakarta 12950
}

\begin{abstract}
Since 2000, Indonesian tea has experienced a lot of problems such as land use change of plantation, lower selling prices, and low productivity. The objectives of this study are to analyze the competitiveness of tea in Indonesia and formulate priority improvements that can support the increasing competitiveness of Indonesian tea. The methods used to analyze the competitiveness were the Revealed Comparative Advantage (RCA) and the Export Product Dynamics (EPD), and to formulate strategies to increase competitiveness, Importance Performance Analysis (IPA) was applied. Based on RCA, the types of Indonesian tea which have strong competitiveness are HS 090210 and HS 090240. The EPD analysis showed that only tea of HS 090210 is in the rising star position, while the HS 090220, HS 090230 and HS090240 tea types are on the retreat position. Based on IPA, sub-determinants which are priority to improve are in quadrant $A$ (under act) consisting of five sub-factors, namely the availability of human resources with the capbility of production management, marketing and possess an entrepreneurial spirit; availability and ease of access to capital; strengthening of the structure of Indonesian tea agribusiness; the government policies in improving domestic demand conditions and in encouraging the development of tea processing industry.
\end{abstract}

Keywords: competitiveness, tea, RCA, EPD, IPA

\begin{abstract}
ABSTRAK
Sejak tahun 2000, teh di Indonesia mengalami banyak permasalahan seperti alih fungsi lahan perkebunan, harga jual teh yang rendah, dan rendahnya produktivitas. Tujuan dari penelitian ini adalah menganalisis daya saing teh di Indonesia dan merumuskan prioritas perbaikan yang dapat mendukung peningkatan daya saing teh Indonesia. Metode yang digunakan untuk menganalisis daya saing adalah Revealed Comparative Advantage (RCA) dan Export Product Dynamic (EPD), dan perumusan strategi peningkatan daya saing menggunakan Importance Performance Analysis (IPA). Berdasarkan RCA, teh Indonesia yang memiliki daya saing yang kuat adalah HS 090210 dan HS 090240. Pada analisis EPD menunjukkan bahwa hanya teh dengan HS 090210 saja yang berada pada posisi rising star, sementara HS 090220, HS 090230, dan HS090240 berada pada posisi retreat. Berdasarkan IPA, sub determinan yang yang mendapatkan prioritas perbaikan berada pada kuadran A (under act) yang terdiri dari lima sub-faktor, yaitu ketersediaan sumberdaya manusia yang menguasai manajemen produksi, pemasaran, dan berjiwa wirausaha; ketersediaan dan kemudahan akses terhadap permodalan; penguatan struktur agribisnis teh Indonesia; kebijakan pemerintah dalam meningkatkan kondisi permintaan domestik; dan kebijakan pemerintah dalam mendorong pengembangan industri pengolahan teh.
\end{abstract}

Kata kunci: daya saing, teh, $R C A$, EPD, IPA

\footnotetext{
${ }^{1}$ Corresponding author:

Email: jauharsamudera@gmail.com
} 


\section{INTRODUCTION}

In 2007, Indonesia was the seventh largest tea producer in the world contributing to $3.76 \%$ of world tea production. However, in 2013 it dropped to the eighth position in the world with only accounted for 2.77 percent of world tea production (UNCOMTRADE 2015). This was shown by the decrease in the national tea production from 2007 to 2013. One of the factors causing the decline in the national tea production includes the conversion of tea plantation areas into areas for other commodities. Another factor that led to decrease of the production of Indonesian tea is the low level of productivity of tea plantation in Indonesia compared to that of other countries. In 2013, the productivity of the Indonesia tea plantations amounted to only $1210.0 \mathrm{~kg} / \mathrm{ha}$, and Indonesia was in the thirty third level in the world in terms of level of productivity of tea plantations.

Indonesian tea export is generally divided into green tea and black tea. During the period of 2008-2014, Indonesian tea was exported mostly in the form of black tea despite its fluctuated development in this period. Based on BPS (2015), in 2008, Indonesia exported 96,210 tons of tea i.e. $12.53 \%$ of green tea and $87.47 \%$ of black tea, while in 2014 Indonesia only exported 66,399 tons of tea i.e. $18.28 \%$ and $81.72 \%$ of green tea and black tea respectively. Indonesian tea export performance is influenced by several factors, among others, demand and supply of tea in the international market, types and quality of tea, world tea prices, and trade barriers from the export destinations (Suprihatini, 2005; Kustanti and Widiyanti, 2007). Based on UNCOMTRADE (2015), the annual average price of tea in Indonesia from 2003 to 2012 continued to increase. In 2003, the prices of Indonesian tea was US\$1,087/ton and in 2012 the price of Indonesian tea reached US\$2,237/ton; however, these prices were still lower than those of Sri Lanka, China, Kenya, and India. This indicates that the quality of Indonesia exported tea is still lower than that of the four countries. Sri Lanka which is the world's fourth largest tea producer produces the best quality of tea so that its price reaches US\$4,407/ton. The prices of tea from China, Kenya and India respectively amounted to US\$ 3,324/ton, US\$2,714/ton and US\$3,046/ton. Competitive advantage in tea can be met if its quality and consistency are guaranteed. Besides, the necessary policies and regulations that support the government in the development of tea in Indonesia are required
(Suprihatini, 2005; Nurunisa and Baga, 2012; Arifin, 2013).

An advantage of a product in the market shows the condition of its competitiveness. The approach is often used to measure competitiveness of a commodity seen from two indicators of comparative advantage and competitive advantage (Porter, 1990). The theory of comparative advantage described by David Ricardo is that a country will specialize in producing and exporting a commodity that has smaller absolute losses (a commodity which has comparative advantages) and import commodities which have larger absolute losses or have comparative disadvantages. The concept of competitive advantage is a concept indicating that the natural condition should not necessarily become an inhibiting factor because the advantage of a product can basically be fought and competed with various struggles. Global competitive advantage or Diamond Porter theory consists of interactions of four determinants: 1) the factor condition; 2) demand condition; 3) related industries and supporting industries; 4) corporate strategy, business structure and competition as well as two supporting factors of opportunities and government roles (Porter, 1990).

One factor of Berlian Porter is a factor condition describing the availability of land for development of tea plantations that provides the potentials to further enhance tea production in Indonesia. In 2013, 45.79\%, $30.75 \%$, and $23.46 \%$ of the Indonesian tea plantations were owned by the smallholder enterprises, state plantations and private estates respectively (BPS, 2015). The government through the Indonesian Tea Board initiated the National Tea Agribusiness Rescue Movement through the establishment of cooperative clusters where the people become the partners of the state and private estates. The functions of such partnerships include providing a guaranteed market (offtaker), cutting the marketing chain to be more efficient, improving the professionalism of the corporations significantly, and simultaneously fostering farmerowned farm management under one management. Indonesian tea market structure has a monopsony tendency in the upstream and monopoly tendency in the downstream. This market structure puts farmers at the end of the supply chain with a very weak bargaining position so that they cannot set prices (Kustanti and Widiyanti, 2007). Meanwhile in Jakarta Tea Auction (JTA), the market structure applied is oligopsonistic, 
as shown by the dominance of a few buyers when the auction takes place (Nurunisa and Baga, 2012). Prices of tea in JTA are not influenced by prices of tea at Colombo Tea Auction (Sri Lanka) and Guwahati Tea Auction (India). Changes in prices that occur in Colombo and Guwahati auction markets are not transmitted to JTA (Adinugroho and Harmini, 2011). JTA market structure is oligopsony which causes the price transmissions from the consumer market to farmers to be asymmetric in the sense that if price increases at the consumer level, the increase is not passed on to farmers quickly and perfectly (Irawan, 2007). Since 2006 up to now tea consumption in Indonesia has increased. In 2012, the level of tea consumption per capita in Indonesia was 350 gram/capita/year (BPS, 2015). These conditions must be addressed by the plantations or companies with their existing capacity to perform a gradual change (incremental) toward the current technologies based on customer demand (Suprihatini et al. 2005). The appropriate strategy to position tea products can be carried out by promoting benefits contained in tea (Adam, 2011). However, the people who have tradition of drinking tea in Indonesia have less appreciation in regards to quality, for the majority of tea consumed still has a lower quality compared to the Taiwanese who believe that drinking tea is identical to health (Herlambang et al. 2011)

In order to protect the domestic market, the government issued import regulations covering aspects of tariff barriers and non-tariff barriers. The form of tariff barriers that has been implemented by the government is import tariffs on tea. Currently import tariffs on tea in Indonesia are applied on two types of tea i.e. bulk tea (HS 090220 and HS 090240) of approximately 5\% (for AFTA 0\%), and non-bulk tea (HS 090210 and HS 090230) of 5 percent. This tariff barrier policy is still considered to be unable to protect the domestic market; therefore, the government is expected to increase import tariffs on tea as a raw material by $25 \%$ and on tea as a finished product by $40 \%$ by considering the highest level of import tariff allowed by the WTO (Suprihatini, 2015). Suwandari and Soetriono (2010) stated that the increase in import tariffs may lead to the increase of domestic commodity prices, so the impact of the increase in import tariffs may increase the competitive advantage of the community and industrial estates and increase the government protection towards domestic commodity prices. In addition to the tariff barrier policy, there is also a policy of non-tariff barriers i.e. the quality requirements based on ISO and Euro compliants that import of low quality tea which is counter-productive to efforts to improve quality will be reduced and longterm goals of regulations to tea imports are directed at reducing the amount of imported tea bulk and replacing it with domestic production (Sumitro, 2012). Currently, the world tea producers are trying to produce tea with excellent quality, so the competition becomes tougher, thus every country should have a specialization and ability to compete for the existing market.

Indonesia Tea still faces a variety of issues affecting competitiveness, such as the low level of tea productivity and low selling price in the international market, and market structure of Indonesian tea has a tendency of monopsony in the upstream and monopoly in the downstream, and the existing policies of tariff barriers and non-tariff barriers have not optimally protected domestic markets. This study is different from the previous research as it applies Revealed Comparative Advantage (RCA), Export Product Domestic (EPD), and Importance Performance Analysis (IPA) analyses to analyze the competitiveness of Indonesian tea. The objectives of this study are to analyze the comparative advantage and competitive advantage of the Indonesian tea in the international market and formulate improvement priorities that can support the increasing competitiveness of Indonesian tea.

The tea commodities discussed in this study include HS 090210 (green tea not fermented) in immediate packing of a content not exceeding $3 \mathrm{~kg}$ ); HS 090220 (Other green tea (not fermented)); HS 090230 (black tea (fermented) and partly fermented tea, in immediate packing of a content not exceeding $3 \mathrm{~kg}$ ); and HS 090 240 (of black tea (fermented) and other partly fermented tea)

\section{METHODS}

The data used are primary and secondary data. The primary data came from experts chosen intentionally based on the consideration of their expertise and practical experience through interviews using a structured questionnaire. The secondary data were obtained from the Central Bureau of Statistics, UN Commodity and Trade Database, and other literature. The respondents to the questionnaires were selected based on purposive sampling technique, with the consideration of their expertise and practical experience. They include Sultoni Arifin (Indonesia Tea Board Executive 
Director), Rahdi Sumitro (Senior Researcher Indonesia Tea Board); Rohayati Suprihatini (Head of Research PPTK Gambung), Dadang Juanda (Marketing Manager Tea, Coffee and Cocoa PT. Kharisma Joint Marketing Nusantara (PT. KPBN)), and Dewi Fajar (Assistant Manager of Quality Control KPBN). In achieving the expected goals, the analysis to support this research was used. Further explanation of the data analysis process can be seen in Table 1.

Porter diamond theory can explain the sub-factors affecting the competitiveness of a particular industry or commodity (Puspita and Baga, 2013; Narulita et al. 2014; Savitri et al. 2014) in detail. RCA is used to measure the structure of a country's exports, where the ratio of the two kinds of ratios is taken into account i.e. the export ratio of every economy sector towards the total exports in a country, which is relative to the ratio of world exports for each sector related to total world exports. RCA was chosen because it can mitigate the impact of the effects of the government intervention, so that the comparative advantage of a commodity over time can be seen clearly (Ahtar et al. 2009; Shoufen et al. 2011; Natalia and Nurozy, 2012; Yanti and Widyastutik, 2012; Kathuria, 2013; Kuldilok et al. 2013; Ozcelik and Erlat, 2013; Rifin, 2013). According to Batra and Khan (2005) RCA index is formulated as follows:

$$
\mathrm{RCA}=\left(\mathrm{X}_{\mathrm{ij}} / \mathrm{X}_{\mathrm{j}}\right) /\left(\mathrm{X}_{\mathrm{iw}} / \mathrm{X}_{\mathrm{w}}\right)
$$

Description: $X_{i j}=$ export value of $i$ sector of country $j$; $X_{j}=$ Total exports of country $j$; $X_{i w}=$ total world exports of sector I; dan $\mathrm{X}_{\mathrm{w}}=$ total world exports.
EPD indicator is used to identify the market position of a commodity at a certain destination and determine the performance of the commodity, whether it has a dynamic growth or not in regards to rapid growth (Nabi and Luthria, 2002). If export growth of a product is above average continuously in the long term, this product can be an important source of export revenue for the country. Furthermore, if a dynamic product that has the characteristics of specific production, it will become important information on opportunity export in conjunction with a similar product (Hasibuan et al. 2012; Kanaya and Firdaus, 2014; Pradipta and Firdaus, 2014; Zuhdi and Suharno, 2015). To calculate the market share of exports in a country (i) and market share of a product (n product) in world trade mathematically, the following equation is used:

$\mathrm{X}$ axis: Growth in i export market share (Indonesia)

$$
\frac{\sum_{t=1}^{t}\left(\frac{x_{i n}}{X_{n}}\right)_{t} \times 100 \%-\sum_{t=1}^{t}\left(\frac{x_{i n}}{X_{n}}\right)_{t-1} \times 100 \%}{T}
$$

$\mathrm{Y}$ axis: Growth in $\mathrm{n}$ product market share

$$
\frac{\sum_{t=1}^{t}\left(\frac{X_{n}}{X}\right)_{t} \times 100 \%-\sum_{t=1}^{t}\left(\frac{X_{n}}{X}\right)_{t-1} \times 100 \%}{T}
$$

Description:

$\mathrm{X}$ : export value; $\mathrm{T}$ : number of years; and $\mathrm{t}$ : $\mathrm{t}$ year

Export Product Domestic (EPD) can be converted into a form of quadrant-shaped figure with the $\mathrm{X}$ axis reflects increased market share of exports in the world trade or market attractiveness and Y-axis reflects increased product market share in the world trade or business strength information. The position of national export product can be seen in Figure 1.

Table 1. Data analysis process

\begin{tabular}{lll}
\hline \multicolumn{1}{c}{ Stages } & \multicolumn{1}{c}{ Analysis Framework } & \multicolumn{1}{c}{ Outputs } \\
\hline $\begin{array}{l}\text { Comparative advantage } \\
\text { analysis }\end{array}$ & $\begin{array}{l}\text { Revealed Comparative } \\
\text { Advantage (RCA) } \\
\text { Export Product Domestic (EPD) }\end{array}$ & $\begin{array}{l}\text { Information on the value of comparative advantage of } \\
\text { Indonesian tea } \\
\text { Information on the position of Indonesian tea market on } \\
\text { the international market and its performance } \\
\text { Information on the sub-determinant of competitiveness } \\
\text { based on the components of berlian porter (resource } \\
\text { Identification of the } \\
\begin{array}{l}\text { determinant factors } \\
\text { Indonesian tea }\end{array}\end{array}$ \\
$\begin{array}{l}\text { Berlian Porter } \\
\text { supporting industries, company strategy, structure and } \\
\text { Measurement of the level } \\
\text { of interest and performance } \\
\text { in the determinants of } \\
\text { competitiveness }\end{array}$ & $\begin{array}{l}\text { Importance Performance } \\
\text { Analysis (IPA) }\end{array}$ & $\begin{array}{l}\text { Information on the position of the sub-determinant } \\
\text { priority on the competitiveness determinant factor } \\
\text { in the Cartesian diagram. For the sub-factors which } \\
\text { are in the quadrant of under act, the increase of their } \\
\text { performances should be prioritized. }\end{array}$ \\
\hline
\end{tabular}


Importance Performance Analysis (IPA) was introduced by Martilla and James (1977) to measure the relationship between the priority of improving the quality of products/ services that are also known as Quadrant analysis and consumer perceptions. IPA has been generally accepted and used in various fields of study because it is easy to be applied and can display analysis results which facilitate performance improvement proposals. In the assessment of IPA, the study required questionnaires to be filled out by the experts on the importance and performance of each existing sub-factor. Each criterion has a score of a specific answer based on a Likert scale of 1-5 (Wong et al. 2011; Farid et al. 2013). Results of the assessments on the level of interest and level of performance put into a Cartesian diagram, as shown in Figure 2, with the positioning determinant of each subfactor previously assessed are as follows:

$$
X \text { axis }=\frac{\sum_{i-1}^{n} \bar{\alpha}_{1}}{N} Y \text { axis }=\frac{\sum_{i-1}^{n} b_{1}}{N}
$$

Description: $\mathrm{X}$ : the average scores of the average assessments of factor performances; Y: the average score of the average assessments of factor interest; $\mathrm{N}$ : number of assessment factors.

Based on the background and the formulation of the problems described earlier, this study conducted the analysis of competitive advantage toward the components of competitiveness determinants of Indonesian tea both comparatively and competitively. This study formulated improvement priorities that can support the increased competitiveness of Indonesian tea based on the level of performance and interest factors of each determinant of competitiveness. The information generated is expected to have implications for the strategy of increasing the competitiveness of Indonesian tea. The conceptual framework is shown in Figure 3.

\section{RESULTS}

\section{Comparative Advantage of Indonesian Tea}

The RCA index of Indonesian tea analyzed consists of four HS (Harmony System) codes of 090210, 090220, 090230, and 090240. Tea with HS codes of 090220 and 090240 belongs to bulk tea, while tea with HS codes of 090210 and 090230 belongs to packaged tea. From 2000 to 2014, the Indonesian tea commodities with HS codes of 090210 (packaged green tea) and of 090240 (bulk black tea) had competitiveness when viewed from the Indonesia RCA index value. This is because the index values of the two commodities are already greater than one, indicating this product already has a comparative competitiveness. RCA value of tea with HS code of 090220 tends to fluctuate, and since 2011 the value has been smaller than one. The same thing occurred at the RCA value of tea with HS code of 090230 whose index value is smaller than one, and its value which was greater than one only occurred in the period of 2004-2007. The RCA index values of Indonesian tea with HS codes from 2000 to 2014 can be seen on Figure 4.

Growth of commodity share

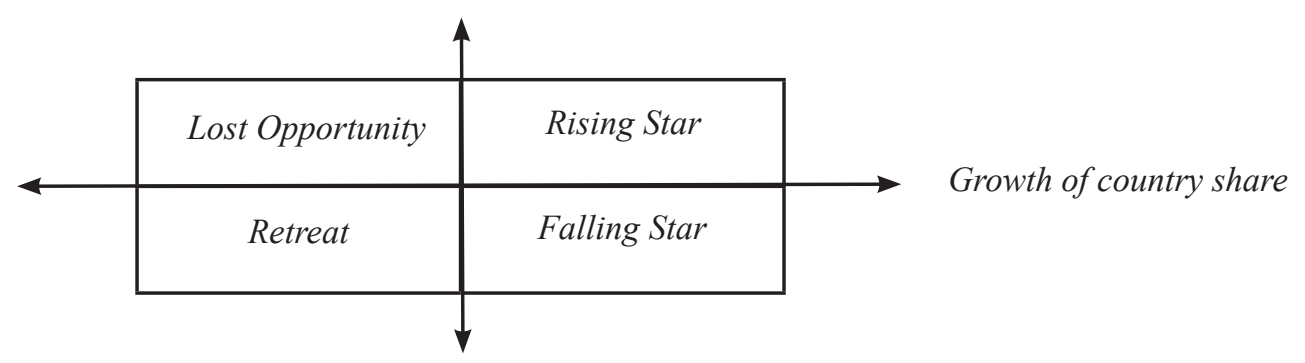

Figure 1. The position of export product of a country in the world market (Nabi and Luthria, 2002).

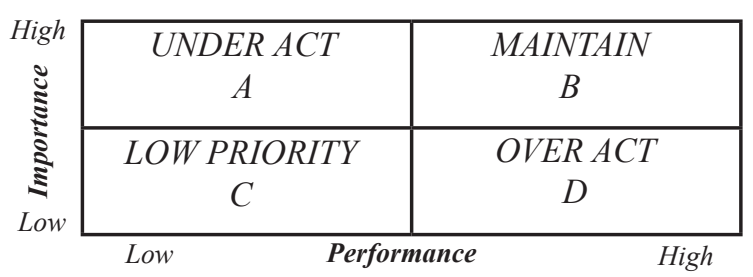

Figure 2. Cartesius diagram of Importance Performance Analysis (IPA) 


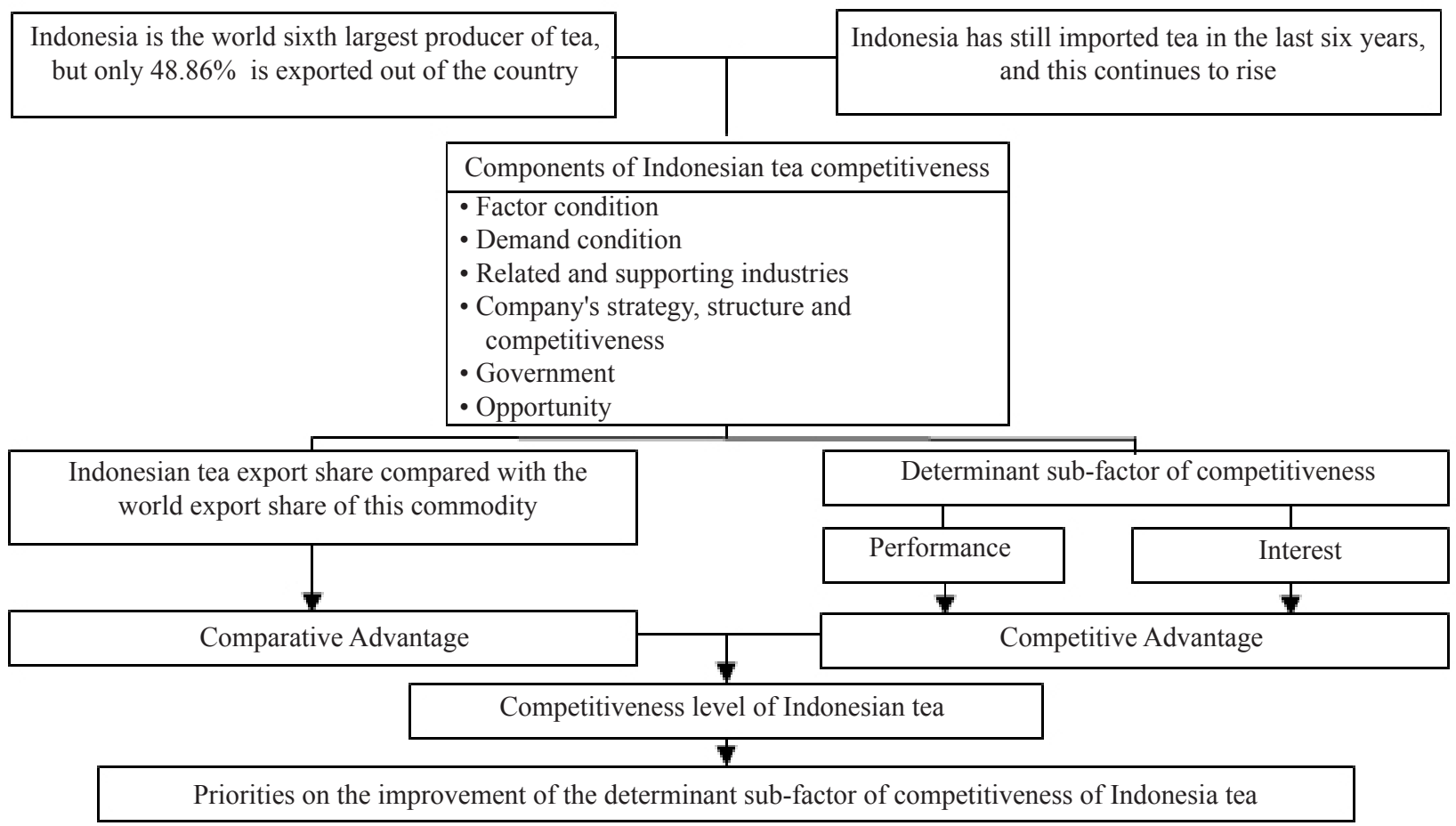

Figure 3. Research framework

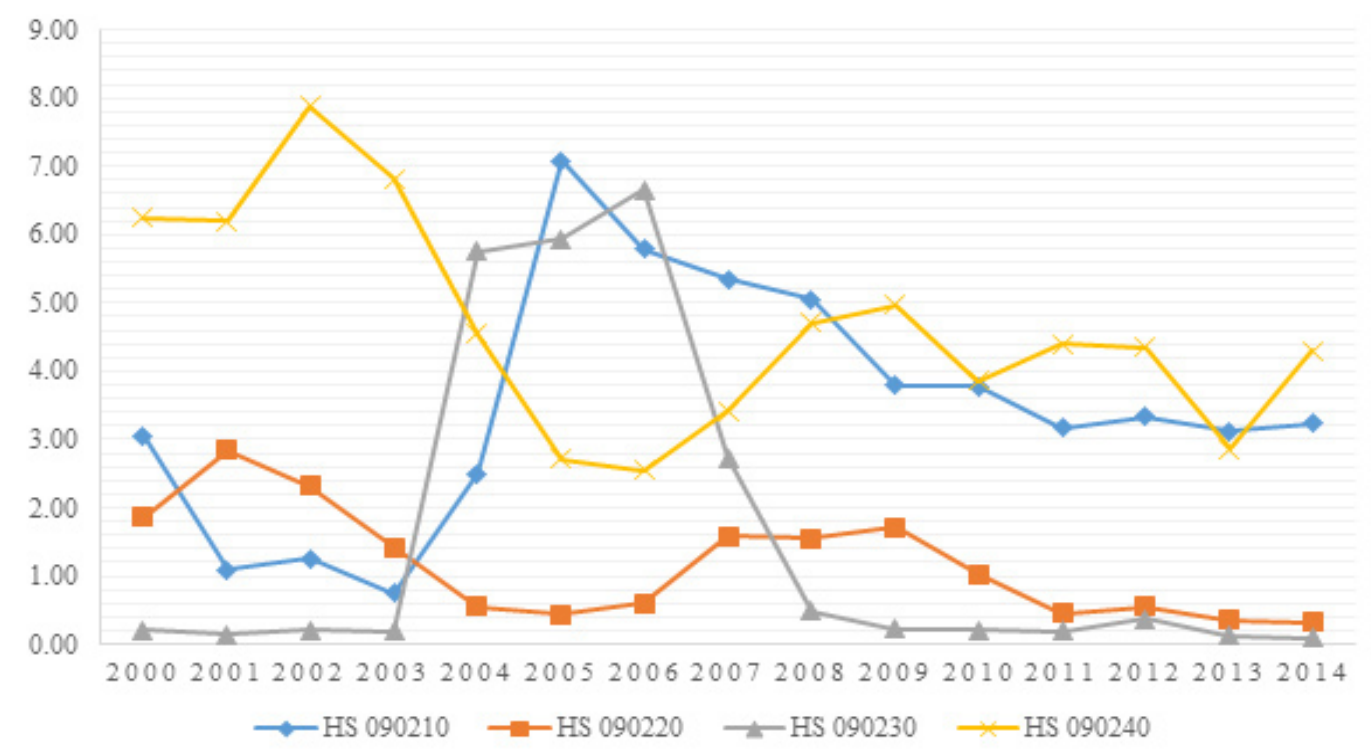

Figure 4. The RCA index value of Indonesia Tea in the period of $2000-2014$ (UNCOMTRADE, 2015) (processed)

Measurement of competitiveness was continued using EPD method to identify the market position of a commodity at a certain destination and to determine the performance of the commodity. EPD method will produce a matrix consisting of the attractiveness of the market (demand growth) and information business strength (market share). Indonesian tea EPD value can be seen in Table 2 .
Based on the EPD matrix from 2000 to 2014, exports of Indonesian tea that had good performances only tea with HS code of 090210 awarded as the rising star which is an ideal condition in which Indonesia gained a dynamic market share for a commodity which has grown or risen rapidly. As for tea with HS codes of 090220, 090230, and 090240, Indonesia achieved the retreat predicate showing that the performance of Indonesian exports was stagnant or even went down, and this condition is not desirable in market. 
Determination of prospective tea in the international market is carried out by combining tea the RCA highest value at the previous RCA analysis and EPD analysis results that are not in the retreat group. Therefore, tea with HS code of 090210 is more prospective to be developed in the international market, while tea with HS codes of 090220,090230 and 090240 should be optimized in the domestic market. This is supported by an increase in domestic tea consumption in which the amount amounted to 62,745 tones and 90,987 tons in 2006 and 2014 respectively (BPS, 2015). The current domestic tea consumption reaches $69 \%$ of black tea and $31 \%$ of green tea with. In general, tea consumption in Indonesia includes $50 \%$ of loose tea package, 35\% of teabag and $15 \%$ of ready to drink tea (BPS 2015).

\section{Competitive Advantage of Indonesia Tea}

Importance Performance Analysis (IPA) built in Berlian Porter framework that is used to determine the condition of competitiveness of Indonesian tea produces some sub-determinants that have importance and performance values on each factor. In the resource factor, the highest performance and interest include the availability of human resources of domestic marketers and exporters who are able to create a market ( 3.80 and 4.80 ) while the lowest performance is the availability of infrastructure (2.60). This lowest performance is due to the uneven distribution of infrastructure at the centers of tea production, and in the development of tea plantations, infrastructure should be built comprehensively and integrated with each other. On the demand factor, the highest performance and interest include the amount of large export market demand (4.20 and 4.60) while the lowest performance include awareness of using natural-based products as part of the lifestyle and promotion of exports (3.80). This is because tea culture developed in Indonesia does not greatly appreciates the quality since the majority of tea consumed is of low quality. On factors related to supporting industries, the highest performance and interest is the development of downstream tea product-based derivative industry and supports from the research institutions (government, universities, private companies, associations) to solve the tea agribusiness problems ( 4.00 and 4.60 ) while the lowest performance is the growth of tea plantations and handling of raw materials supply for the downstream tea industry (3.40). This occurs because the supporting input industries for the downstream tea industries such as paper for tea bag, straps for tags, bottle packaging for ready to drink tea, and tea flavor still import them at a reasonably high tariff. On the factor of corporate strategy, structure and competitiveness, the highest performance and interest include willingness and capacity to compete globally (3.60 and 4.60) while the lowest performance is in strengthening the structure of Indonesian tea agribusiness (3.00). The reason for this is that the National Tea Agribusiness Rescue Movement (GPATN) which was initiated by the Indonesian Tea Board through the establishment of cooperative clusters still has not run optimally. On the government factor, the highest performance is the government role in providing information, market access and export promotion (4.00) and the highest interest is the government policy which encourages the development of tea processing industry (4.60) while the lowest performance is the government policy which provides a conducive business climate (2.80).

\section{Competitiveness Improvement Priority of Indonesian Tea}

From the results of the assessment of the determinant factors of competitiveness of Indonesian tea using IPA, the position of each sub-determinant that have been identified into four quadrants was identified i.e. A, B, $\mathrm{C}$, and D. Priorities for improved performance resulted from IPA assessment are shown in Figure 5.

Table 2. EPD value of Indonesian tea

\begin{tabular}{ccccc}
\hline Country & HS Codes & X Axis & Y Axis & Position \\
\hline Indonesia & 090210 & 0,00095708 & 0,00028709 & Rising star \\
& 090220 & $-0,00000400$ & $-0,00000033$ & Retreat \\
& 090230 & $-0,00000134$ & $-0,00000214$ & Retreat \\
& 090240 & $-0,00007851$ & $-0,00000975$ & Retreat \\
\hline
\end{tabular}




\begin{tabular}{|c|c|c|}
\hline \multirow{2}{*}{ 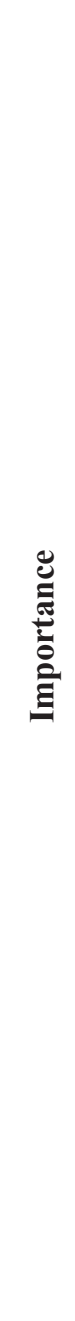 } & $\begin{array}{l}\text { Under Act (A) } \\
\text { 1. Availability of human resources in } \\
\text { production management, marketing, and with } \\
\text { entrepreneurial spirit } \\
\text { 2. Availability and ease of access to capital } \\
\text { 3. Strengthening of agribusiness structure of } \\
\text { Indonesian tea } \\
\text { 4. Government policy in improving domestic } \\
\text { demand conditions } \\
\text { 5. Government policy in encouraging the } \\
\text { development of tea processing industry }\end{array}$ & $\begin{array}{l}\text { Maintain (B) } \\
\text { 1. Availability of high quality tea seeds } \\
\text { 2. Availability of human resources mastering } \\
\text { efficient harvest and post-harvest technologies } \\
\text { 3. Availability of human resources for both } \\
\text { domestic and exporter marketers who are able to } \\
\text { create market } \\
\text { 4. Availability of research results to the } \\
\text { development of Indonesian tea } \\
\text { 5. Availability of market information } \\
\text { 6. Amount of domestic demand } \\
\text { 7. Development of tea downstream based-products } \\
\text { of derivative industry } \\
\text { 8. Support for research institutions (government, } \\
\text { universities, private companies, associations) to } \\
\text { solve problems in tea agribusiness } \\
\text { 9. Willingness and ability to compete globally }\end{array}$ \\
\hline & $\begin{array}{l}\text { Low Priority (C) } \\
\text { 1. Availability of land for tea plantation } \\
\text { 2. Availability of skillful human resources in tea } \\
\text { plantations and in appropriate farming method } \\
\text { 3. Availability of institutions/ Association for tea } \\
\text { agribusiness agents } \\
\text { 4. Awareness of using natural based-products as } \\
\text { part of a lifestyle } \\
\text { 5. Promotion of exports } \\
\text { 6. Development of tea plantations that supply raw } \\
\text { materials for the downstream industry } \\
\text { 7. The government policy in maintaining } \\
\text { availability of high quality of raw materials } \\
\text { sustainably } \\
\text { 8. The government policy in the provision of a } \\
\text { conducive business climate }\end{array}$ & $\begin{array}{l}\text { Over Act (D) } \\
\text { 1. Large amount of export market demand } \\
\text { 2. Intensity of competition in the country } \\
\text { 3. Role of the government in capacity building of } \\
\text { human resources } \\
\text { 4. Role of the government in providing } \\
\text { information, market access and export } \\
\text { promotion }\end{array}$ \\
\hline & & \\
\hline
\end{tabular}

Figure 5. Priorities for improved performance resulted from IPA assessment results

\section{Managerial Implications}

Based on the results of the study, a number of implications for the related parties to improve the competitiveness of Indonesian tea can be formulated. Some implications which become the priority for improvement and come primarily from the determinant factors of competitiveness are in quadrants A and B. For the business agents, they are expected to strengthen their partnership or cooperation in order to enhance the ability to compete in the global market, with a variety of innovations in order to be able to produce high quality of tea derived products with competitive prices.

The government must issue several policies, among others: 1) to ensure the availability of high quality of seeds for tea plantations by optimizing the role of the Research Center for Tea and Quinine, Indonesia Tea
Board, and relevant stakeholders; 2) to conduct training and technical assistance in terms of efficient tea harvest and postharvest technologies, production management and marketing for the relevant industry; 3 ) to encourage the domestic tea industry to optimize the domestic market, especially for tea with HS codes of 090220 , 090230, and 090240; 4) to build the synergy of various stakeholders of tea in Indonesia and reduce overlapping roles of stakeholders; 5) to encourage the development of tea downstream product-based derivative industry; 6) to encourage financial institutions of both banking and non-banking to assist Indonesian tea agribusiness in terms of ease of access to capital; and 7) to optimize the role of National Tea Agribusiness Rescue Movement in strengthening the structure of the Indonesian tea agribusiness, making the marketing chain efficient and facilitating problem solving related to the Indonesian tea agribusiness. 
The academics are expected to conduct innovative and applicable research to develop efficient tea industry and tea downstream industry and to cooperate with the government, private sectors, and associations in solving problems related to Indonesian tea agribusiness. As for the association, it needs to strengthen the relationship among the tea agribusiness agents and make it as a forum to discuss the problems encountered, conduct close collaboration with the government to formulate a program that supports the tea downstream industry and represent tea sub-sector especially its downstream products in the international forums. This is consistent with the result of research by Zacharevic and Dzemyda (2015) which states that the current economic conditions which are increasingly open for human resources, knowledge and ability to create a market becomes more important in order to gain competitiveness in the long term.

\section{CONCLUSIONS AND RECOMMENDATIONS}

\section{Conclusions}

Based on the index value of RCA from 2000 to2014, it is known that the type of Indonesian tea which has competitiveness in the international market is tea with HS codes of 090210 and 090240 whereas tea with HS codes of 090220 and 090230 does not have comparative competitiveness for its index value is less than one. However, when analyzed again using the EPD, only tea with HS codes of 090210 has competitiveness because of its position as a rising star. Meanwhile tea with HS codes of 090220, 090230, and 090240 are not competitive because it is in a retreat position.

Based on the analysis of competitive advantage, there are several performances which need to be improved i.e. availability of infrastructure, awareness of using nature-based products as part of the lifestyle, export promotion, development of tea plantations and handling that supply raw materials for the tea downstream industry to strengthen the agribusiness Indonesian tea agribusiness, and government policies to provide a conducive business climate.

Based on IPA, the sub-determinants which obtain improvement priorities are in quadrant A (under act) which consists of five sub-factors, namely, availability of human resources for production management and marketing with entrepreneurial spirit; availability and ease of access to capital; strengthening of the structure of Indonesian tea agribusiness; government policies in improving domestic demand conditions; and government policies in encouraging the development of tea processing industry.

\section{Recommendations}

RCA and EPD calculation results show that the majority of Indonesian tea exported has weak competitiveness in the international market. Therefore, in implementing a strategy to increase the competitiveness of Indonesian tea, the priorities of improvements generated from the IPA analysis must be considered. In addition, further research on strategies for improving the future competitiveness of Indonesian tea for the betterment of the nation in general and success of Indonesian tea industry in particular is required.

\section{REFERENCES}

Adam RP. 2011. Target pasar dan strategi memposisikan produk teh di pasar teh global. Media Litbang Sulteng 4(2): 125-136.

Adinugroho MF, Harmini. 2011. Transmisi harga teh hitam grade dust Indonesia. Forum Agribisnis 1(2): 183-199.

Ahtar W, Sharif M, Shah H. 2009. Competitiveness of Pakistani fruits in the world market. The Lahore Journal of Economics 14(2): 125-133.

Arifin B. 2013. On the competitiveness and sustainability of the Indonesian agricultural export commodities. ASEAN Journal of Economics, Management and Accounting 1(1): 81-100.

Batra A, Khan Z. 2005. Revealed Comparative Advantage: an Analysis for India and China. New Delhi: Indian Council For Research on International Economic Relations.

[BPS] Badan Pusat Statistik. 2015. Statistik Teh Indonesia 2014. Jakarta: Badan Pusat Statistik.

Farid A, Soemarno, Marsoedi, Setiawan B. 2013. Importance Performance Analysis of the marine tourism in Bawean Island, Indonesia. European Centre for Research Training and Development UK 1(2): 33-41.

Hasibuan AM, Nurmalina R, Wahyudi A. 2012. Analisis kinerja dan daya saing perdagangan biji kakao dan produk kakao olahan Indonesia di pasar internasional. Buletin RISTRI 3(1): 57-70. 
Herlambang ES, Hubeis M, Palupi NS. 2011. Kajian perilaku konsumen terhadap strategi pemasaran teh herbal di Kota Bogor. Jurnal Pengembangan Manajemen Industri Kecil Menengah 6(2): 143151.

Irawan B. 2007. Fluktuasi harga, transmisi harga dan marjin pemasaran sayuran dan buah. Analisis Kebijakan Pertanian 5(4): 358-373.

Kanaya IA, Firdaus M. 2014. Daya saing dan permintaan ekspor produk biofarmaka Indonesia di negara tujuan utama periode 2003-2012. Jurnal Manajemen \& Agribisnis 11(3): 183-198.

Kathuria LM. 2013. Analyzing competitiveness of clothing export sector of India and Bangladesh, dynamic revealed comparative advantage approach. International Business Journal 23(2): 131-157.

Kuldilok SP, Dawson PJ, Lingard J. 2013. The export competitiveness of the tuna industry in Thailand. British Food Journal 115(3): 328-341.

Kustanti VR, Widiyanti T. 2007. Research on Supply Chain in The Tea Sector in Indonesia. Jakarta: The Business Watch Indonesia.

Martilla JA, James JC. 1977. Importance-performance analysis. Journal of Marketing 41(1):13-17.

Nabi I, Luthria M. 2002. Building Competitive Firms: Incentives and Capabilities. Washington: The World Bank.

Narulita S, Asmarantaka RW, Jahroh S. 2014. Analisis dayasaing dan strategi pengembangan agribisnis kopi Indonesia. Jurnal Agribisnis Indonesia 2(1): 63-74.

Natalia D, Nurozy. 2012. Kinerja daya saing perikanan Indonesia di pasar global. Buletin Ilmiah Litbang Perdagangan 6(1): 69-88.

Nurunisa VF, Baga LM. 2012. Analisis daya saing dan strategi pengembangan agribisnis teh Indonesia. Forum Agribisnis 2(1): 33-52.

Ozcelik SE, Erlat G. 2013. Turki's comparative advantage and dynamic market positioning in the EU market. Topic in Middle Eastern and African Economies 15(2): 42-70.

Porter ME. 1990. The Competitive Advantage of Nations. New York: Free Press.

Pradipta A, Firdaus M. 2014. Posisi daya saing dan faktor yang memengaruhi ekspor buah-buahan Indonesia. Jurnal Manajemen \& Agribisnis 11(2): 129-143.

Puspita AAD, Baga LM. 2013. Analisis daya saing dan strategi pengembangan agribisnis gandum lokal di Indonesia. Jurnal Agribisnis Indonesia 1(1):
9-26.

Rifin A. 2013. Competitiveness of Indonesia's cocoa beans export in the world market. International Journal of Trade, Economics and Finance 4(5): 279-281.

Savitri DA, Sumarwan U, Kurniawan BPY. 2014. Daya saing dan model pemasaran sentra industri usaha kerajinan sangkar burung perkutut. Jurnal Manajemen \& Agribisnis 11(1): 24-32.

Shoufen C, Feng L, Jiao Z. 2011. Export competitiveness of agri-products between China and Central Asian Countries: A comparative analysis. Journal of Canadian Social Science 7(5): 129-134.

Sumitro R. 2012. Rapat pengurus Dewan Teh Indonesia. http://indoteaboard.org/z1/?p=571. [1 Oktober 2015].

Suprihatini R, Sa'id EG, Marimin, Mangunwidjaja D. 2005. Analisis kondisi komponen-komponen teknologi pengolahan di industri teh curah Indonesia. Jurnal Teknologi Industri Pertanian 14(3): 101-106.

Suprihatini R. 2005. Daya saing ekspor teh Indonesia di pasar teh dunia. Jurnal Agro Ekonomi 23(1): $1-29$.

Suwandari A, Soetriono. 2010. Analisis kebijakan kopi robusta dalam upaya meningkatkan daya saing dan penguatan revitalisasi perkebunan. Jurnal Sosial Ekonomi Pertanian 4(3): 60-76.

Suprihatini R. 2015. Policies recommendations to safe Indonesian Tea Plantation. Di dalam: Prosiding International Conference Green Agro - Industry 2015: hlm 1-7.

[UNCOMTRADE] United Nations Commodity Trade Statistics Database. 2015. Export commodities based on HS code. http://comtrade.un.org/db/. [1 Oktober 2015].

Wong MS, Hideki N, George P. 2011. The Use of Importance-Performance Analysis (IPA) in evaluating Japan's e-government services. Journal of Theoretical and Applied Electronic Commerce Research 6(2): 17-30.

Yanti L, Widyastutik. 2012. Daya saing produk turunan susu Indonesia di pasar dunia. Jurnal Manajemen \& Agribisnis 9(3): 183-193.

Zacharevic G, Dzemyda I. 2015. Global competitiveness of exporting business: the case study of Lithuania. Science - Future of Lithuania 7(2): 253-261. https://doi.org/10.3846/mla.2015.777.

Zuhdi F, Suharno. 2015. Analisis daya saing ekspor kopi Indonesia dan Vietnam di pasar ASEAN 5. Habitat 26(3): 152-162. 